\title{
Metaphors and critical incidents: Introduction to a methodological approach derived from expressions of librarian professional identity
}

\author{
Cameron M. Pierson, Anne Goulding, and Jennifer Campbell-Meier
}

\begin{abstract}
Introduction. This paper introduces the metaphorical-critical incident technique where elicitation of metaphors is combined with the critical incident technique to study public librarians' professional identity. A new methodological analytical framework is presented to elicit conceptualisations of professional identity and to derive meaning from them.

Method. A questionnaire was administered online to public librarians in New Zealand. The combined elicitation of metaphors and critical incidents were the only substantive open-ended questions and responses were optional. Only complete responses to all open-ended questions were analysed Analysis. Qualitative analyses were conducted on the metaphors and critical incidents data. The study employed an inductive approach in analysing the responses to the questions eliciting metaphors and critical incidents. Excel was used to arrange notations from the content analysis.

Results. Findings support an integrative analytical framework for the joint analysis of metaphors and critical incidents, accommodating a variety of analytical foci. Critical incidents tended to be key data points, providing reasoning for the worldview presented in metaphors.

Conclusions. Results indicate a viable methodological and analytical approach. Mutual support can be established between metaphors and critical incidents in the analytical framework. This approach establishes a link between worldview as expressed by metaphors and critical incidents and their meanings.
\end{abstract}

\section{Introduction}

Social, technological, and professional changes in recent decades have called into question what it is to be a librarian as the nature of information mediation is continuously evolving. The dynamic relationship between patron, library, and librarian continues to change, in no small part due to information and communication technologies (Nelson \& Irwin, 2014). While the so-called crisis in librarianship has been the focus of various discussions with differing emphases (e.g., Bak, 2002; Bennett, 1988; Harris, 1992), at their core is the issue of identity. Professional identity, therefore, can serve as an indicator of institutional interaction with society, since perception of identity influences discourse and behaviour (Sundin \& Hedman, 2009). Understanding of professional identity can account for how service delivery can influence outside perception of the practitioner and the libraryas-institution (Peters, 2013). Better understanding of how professionals perceive their identity is of significant value in discussions concerning the place of the library in $21^{\text {st }}$ century society and beyond.

Isolating identity, however, is difficult because it is a complex, often contradictory, construct. A promising approach for exploring identity lies with the combination of two methods: elicitation of individual metaphors of perception of the profession and the self within it, and the critical incident technique. This combination provides the potential for extended analysis; the description of critical incidents can provide further context, and suggested reasoning, for the implicit and explicit worldviews presented by elicited metaphors. Where metaphors may seem inconsistent, the addition of critical incidents extends analytical capacity.

This paper reports on the combined metaphorical-critical incident technique (MCIT), a new methodological approach. This approach is illustrated using selected findings from a questionnaire of public librarians' professional identity employing a metaphorical approach in combination with the critical incident technique. Results indicate that metaphors and critical incidents can be analysed together to support one another, providing suggested reasoning for and further depth to participant responses. The emerging framework provides a powerful new tool by which to examine professional identity. 


\section{Literature review}

The literature review begins by discussing the construct of professional identity and its relation to librarians. Next, it discusses previous methodologies used to examine librarian professional identity and the parent methodologies of the approach outlined in this paper.

\section{Professional identity}

A person's pre-existing identity forms the basis of their professional identity (Sundin \& Hedman, 2009; Trede et al., 2012). Professional identity is the product of the impact the organizational and/or professional life has had on one's understanding of self within those contexts (Whyte, 1956/2002). Behaviour and discourse in the professional environment are influenced by this identity, resulting from the varying levels of personal affiliation with a collective (Sundin \& Hedman, 2009). While perceptions of self are influenced by the professional context, such perceptions also contribute to the construction of professional influences (e.g., social practices). Practitioners therefore perceive, interact with, and create certain contextualities (Sundin \& Johannisson, 2005). Participation through various forms of communication within the profession acts both to reinforce the collective conceptualization of a shared identity and contribute to its creation (Sundin \& Johannisson, 2005, pp. 38-39).

Professional identity includes negotiation over time between one's perception of pre-existing and professional identity relative to professional and social influences (Wise, 2012). Professional identity presupposes a sociological underpinning of identity where social influences contribute to its development (Pierson et al., 2019). This dynamic underscores the importance of meaning creation through individual perception, informing professional identity.

\section{Librarian professional identity}

Deciding to pursue librarianship is the first step in binding the librarian professional identity to the pre-existing identity (Sare et al., 2012). Professional practice contributes to the definition of a professional identity and its differentiation from other practitioners and professions (Sare \& Bales, 2014; Sare et al., 2012). Equally, professional associations provide access to a common identity and culture (Preer, 2006), which are incorporated to varying degrees by the individual.

Whether positive or negative, critical incidents related to professional identity development can occur at any time in professional practice and can fundamentally influence the developmental process (Frye, 2018). The local context of practice also influences the individual construction of identity (Hicks, 2016). The conceptualisation of librarianship as a co-constructed relationship between patron and librarian (Hicks, 2014a) indicates that perception of individuals and communities outside of the profession (e.g., through stereotypes) plays a role in identity construction (e.g., Pagowsky \& Rigby, 2014). Importantly, however, individual practitioner perception is key to how identity negotiation occurs over time (Sare \& Bales, 2014). Over the course of their career, a practitioner's identity becomes increasingly personalised (Fraser-Arnott, 2017b). For the purpose of this paper, librarian professional identity is defined using Whyte's (1956/2002) conceptualisation. This includes emphasis of the impact of critical incidents on identity development and that perception of this impact informs the course of identity development. This perception additionally influences self- and worldview and is bounded by the dynamics of the Librarian Professional Identity Continuum model developed by the authors (Pierson et al., 2019).

This model reflects the importance of critical incidents on subsequent professional identity development. For example, their influence may reinforce or develop professional identity or contribute to the formation of a new professional identity. Librarian professional identity is additionally bounded by four aspects, the professional identity anchors, which affect the nature of the influence the critical incident will have on professional identity development. These anchors are: socialisation, social interaction within the professional context and the processes in which professional norms and values are internalised; contextuality, outlining the circumstances of the practitioner and their practice; outside perception, indicative of the view non-practitioners hold of the profession and practitioners in a cultural-temporal context, including stereotypes; and individual 
perception, indicative of the practitioner's view of self, profession, and outside perception in a cultural-temporal context. For a full discussion, see Pierson et al. (2019).

\section{Previous methodologies employed in examining librarian professional identity}

Librarian professional identity has been explored mostly through qualitative approaches. Some have employed a range of methods but quantitative methods to gather data from librarians on their professional identity are less frequently used and tend to be coupled with some qualitative aspect (e.g., Greyson et al., 2013). Surveys are more common in studies using multiple methods, though also feature in some exclusively qualitative studies (e.g., Linton, 2016), highlighting the adaptability of surveys.

Turning to the analysis of data, previous studies have coded inductively or deductively as an analytical method (e.g., Ahmed, 2012). Some form of content analysis, however, is heavily used to analyse qualitative data (Fraser-Arnott, 2016, 2017a, 2017b), with thematic coding also a feature of such analysis (Hicks, 2014b, 2016; Hoffman, 2014).

Although Frye (2018) used Gold's (1996) critical event approach to investigate the professional identity of early-career school librarians, no previous studies have combined the critical incident technique and a metaphorical approach to explore the topic. We suggest that a combination of the two is a powerful approach to analyse librarian professional identity because the critical incident technique provides illustration of key moments contributing to behaviour and professional identity development, while metaphors help illustrate a person's conceptual understanding of experience and worldview. Employed together, they can provide deep insight into perceptions of professional self in context and antecedents thereof.

\section{Critical incident technique}

The critical incident technique is a flexible set of procedures used to elicit information concerning behaviour and its effects (Flanagan, 1954). Respondents are asked about significant incidents that have occurred in their private or professional lives, often framed around a specific topic. Some have leveraged this technique within a professional identity theoretical framework, highlighting its unique ability in identifying and articulating crucial moments which have influenced conceptualizations, behaviour, and identity development (Hutchins \& Rainbolt, 2017). The critical incident technique provides a way to elaborate on an individual incident or collection of incidents and their lasting effects on behaviour, perception, and identity development. Flanagan's (1954) original definition of an incident is: '... any observable human activity that is sufficiently complete in itself to permit inferences and predictions...' with clear intent and consequences so definite as to dismiss ambiguity, thus making it critical (p. 327). A modification, however, comes from Angelides (2010) who argues that criticality cannot be adequately assessed until the consequences are fully known. Additionally, such incidents may not be grand gestures, but quotidian; the designation of 'incident' and quality of its criticality are from the meaning ascribed to them by respondents.

This technique has proved popular in research (Gogan et al., 2014; Hutchins \& Rainbolt, 2017; Luparell, 2004). Radford (2006), for example, elicited critical incidents from primary school children on their interactions with librarians in New York City. Hughes (2012) used an expanded critical incident approach to explore how international students used information resources.

\section{Metaphorical approach}

The metaphorical approach has found various applications in library research (Hekkala et al., 2018; Marshall, 1990; Poulou, 2003). Metaphors relate two or more constructs, where the abstract is made concrete through comparison (Lakoff, 1987). More than linguistic devices, metaphors help to illuminate conceptual understanding of experience and are a mechanism to frame and communicate perceptions and perspectives. As a cognitive device, they help to expand understanding beyond what is present at a given time, highlight conceptualizations within a worldview, and imply what is hidden (Lakoff \& Johnson, 1980). They are ideal as a mechanism through which an individual can articulate how they understand their reality, and how they participate within it. 
VanScoy (2010) advocates the metaphorical approach for deeper study of library practitioner role perception and its relation to personal perception, and uses it to study librarians undertaking reference and information services across library subsectors (VanScoy, 2016). Hartel and Savolainen (2016) examine the metaphors appearing in iSchool students' pictorial representations of information while Giesecke (2010) examines the various metaphors used for libraries, arguing that librarians have leveraged metaphors since at least the $19^{\text {th }}$ century. Savolainen (2006) uses Lakoff and Johnson's analytical framework to examine Dervin's sense-making metaphor, while Savolainen and Kari (2004) examine spatial metaphors given to the Internet. The use of metaphors for investigating aspects of library and information work is well-established, although no previous studies using metaphors to explore librarian professional identify could be identified.

\section{Combined uses}

Combining the critical incident technique and a metaphorical approach has been limited. Luparell (2004) uses the critical incident technique to explore nursing faculty experiences with discourteous students, mentioning that her participants often used metaphors to describe incidents, though her analytical focus is on the incident rather than the metaphor. Helkkula and Pihlström (2010) employ metaphors with critical incident and narrative inquiry techniques in the information and communication technologies sector to create new service ideas. Cheok et al. (2015) use the metaphor of cultural friction as an analytical framework with critical incident and narrative inquiry techniques to explain cross-cultural service interactions in a tourism sector. Similarly, Gaston et al. (2015) use the critical incident technique, guided by Dervin's (2008) information gap-bridging metaphor in everyday information seeking behaviour in Buddhist Laos. Despite the combination of techniques in previous studies, the authors could identify no studies which use them in combination to examine professional identity. The study reported here tests the feasibility of a novel approach to exploring librarian professional identity which capitalises on the benefits of both the elicitation of metaphors and the critical incident technique identified above.

\section{Research questions}

This paper addresses the following research question:

1. How can metaphors and critical incidents be used together to explore aspects of librarian professional identity?

2. What analytical approach supports the combined interpretive analysis of metaphors and critical incidents?

\section{Methodology \\ Study context}

This paper draws on a wider research project focused on the professional identity of public librarians in New Zealand and using a mixed methods model. Phase one data collection used a questionnaire administered fully online between November 2018 and January 2019. Phase two consisted of in-depth interviews conducted between March and September 2019. This paper presents a methodological approach using only the qualitative data elicited through the questionnaire in Phase one. Questionnaire format was chosen to operationalise aspects of the Librarian Professional Identity Continuum (Pierson et al., 2019), for purposeful selection of interview participants based on responses to open-ended questions, and to maximize reach to potential participants across the country. It also tested the feasibility of the elicitation of this kind of qualitative data through a questionnaire. Pre- and pilot testing of the questionnaire contributed to clear language, reduced ambiguity, and ensured a practitioner focus. Selection criteria for participation in the whole study was: must selfidentify as/consider self a librarian; and must currently work in a public library. The invitation to participate was sent through an electronic mailing list for New Zealand librarians.

The combined elicitation of metaphors and critical incidents was one section of four within the questionnaire. Metaphors were elicited because they are a mechanism through which respondents could frame and communicate their perceptions of the profession and themselves within it, and 
expand understanding beyond what is present at any given time, highlighting conceptualizations within a worldview, and implying what is hidden (Lakoff \& Johnson, 1980). Metaphors are ideal in articulating a scheme by which individuals understand their reality and how they participate within it.

As a flexible way to elicit information on behaviour and its effects, the critical incident technique (Flanagan, 1954) provides a unique method of elaboration on individual or a collection of events and their lasting effects on conceptualizations, behaviour, and identity development (Hutchins \& Rainbolt, 2017). Accommodation of multiple events was built into this questionnaire following feedback from the pre- and pilot testing stages. Feedback indicated that it would be difficult for some librarians to choose only one significant incident contributing to professional identity development and would struggle with this limitation. The fields containing these questions were the only substantive openended questions, all appearing on the same page in the middle of the questionnaire, whereas other sections consisted of closed questions. Open-ended questions were optional. In order, the questions relevant to this paper were:

1. Think about the library profession. By using a metaphor, describe how you view librarianship. A short, generic example might be: "The diamond waves crashed against the neck of the shoreline" or "the sea shone like a diamond."

2. Think about yourself as a librarian. By using a metaphor, describe how you view yourself as a librarian.

3. Think of an important event or events that has/have impacted your identity as a librarian. Please describe the event(s).

4. Please elaborate on what specifically made the event(s) impactful to your identity as a librarian.

\section{Analytical approach}

Data analysis involved an inductive, iterative seven step process:

1: Read all four data points and code for sentiment analysis; connections;

2: Content analysis and recording general notations on themes, keywords, contradictions, or

3: Code for metaphor external consistency analysis;

4: Code for metaphor internal consistency analysis;

5: Code for inter-consistency, whether critical incidents relate to metaphors;

6: Code for metaphor framings;

7: Code for critical incident framing.

These steps are explained in more detail below, following discussion of the overall analytical focus.

While analyses of the metaphors and the critical incidents appear to require different approaches, this study demonstrates that it is possible to apply an integrative analytical framework. Metaphors are usually analysed with a linguistic emphasis, such as grouping by source imagery (e.g., Schmitt, 2005; VanScoy, 2016). Content analysis, however, is a viable alternative analysis in instances where the analytical emphasis has shifted away from linguistic forms and uses towards the subject matter of the metaphor (Poulou, 2003). Content analysis can be understood as 'any qualitative data reduction and sense-making effort that takes a volume of qualitative material and attempts to identify core consistencies and meanings' (Patton, 2002, p. 453). The focus on the meaning of a phenomenon by those who experience it indicates that such meaning is accessed through language (Myers, 2013), shifting the analytical focus away from purely language use to the meaning assigned to language within a context.

The critical incident technique also allows analytical flexibility (Gogan et al., 2014; Radford, 2006). The original technique utilises an inductive approach with mutually exclusive arrangement of incident classification (Flanagan, 1954); an incident is classified within one category, not multiple categories. The expanded critical incident approach (an adaptation) provides binary and thematic classification, while maintaining the inductive approach (Hughes, 2012). In the expanded approach, resulting categories may be inter-connected and clustered according to overarching themes or categories that 
yield a set of critical findings, similar to grounded theory approaches. Others have also employed the inductive approach in conjunction with content analysis (Hutchins \& Rainbolt, 2017).

This study employed an inductive approach in analysing the responses to the questions eliciting metaphors and critical incidents, through an iterative process of the steps outlined above. To be included for analysis, responses needed to display complete and viable responses for all four openended questions. Each instance of analytically viable responses addressing all four open-ended questions is defined as a case. There were 59 cases.

In analysis, first both the metaphor and critical incident data were classified via sentiment analysis. Sentiment analysis contributes to understanding of perception. Affect was a persistent feature in the data, and therefore was deemed an important analytical aspect to include in formal analysis. In particular, the critical incidents provided by respondents often indicated provocation of an emotional reaction. This indicates affective state as an entry point to identity negotiations. As a topic of research in librarianship, the study of affect highlights the importance of examining the interplay of affect, perception, and behaviour (e.g., Kuhlthau, 1991; Mills \& Lodge, 2006; Sloniowski, 2016). Sentiment analysis was coded as: 1 . positive; 2 . negative; 3 . aspects of both; or 4 . ambiguous.

Second, content analysis was performed on all data fields, including thematic analysis for all cases $(\mathrm{N}=59)$. Excel was used to arrange notations from the content analysis. This step was fundamental to ascertaining the relationships between data points. Establishing a relationship, known as interconsistency (discussed below), was also deemed a threshold step to be included for analysis beyond this step. It was deemed that, in the early stages of development, limiting the scope of the data analysis beyond an additional threshold would provide more consistency and clarity of results, thereby reducing likelihood of distortion in framework development. Further discussion, unless otherwise noted, will focus on the 53 cases coded as inter-consistent.

Thematic analysis relied on content analysis to provide core themes of what was being expressed within individual cases. Careful interpretation plays an important role in this step. The data constitutes multiple realities requiring a holistic approach characteristic of the interpretivist paradigm (Pickard, 2013). Exploration of meaning through themes and respondent expression of perception can be achieved using subjective, systematic interpretation with careful reasoning and inference grounded in the data (Zhang \& Wildemuth, 2009). The first author leveraged his previous expertise as a library practitioner in interpretive analysis.

Due to the nature of metaphorical responses, this study defines metaphor as a linguistic device comparing an object, action, or construct with another object, action, or construct. The metaphors were analysed jointly for their external and internal consistencies. External consistency assessed whether the two metaphors (for the library profession and for the individual as a librarian) related thematically at face value, by extension of the imagery employed. Internal consistency assessed whether the two metaphors were linked by a core theme or principle, despite external inconsistency.

For example, respondent 13 described the library profession as 'A safe harbour from rough seas' and their view of them self as librarian as 'being a Ship's Captain for my community'. In this example, a general metaphorical theme (a nautical theme) is maintained through both data points and illustrates external consistency.

Internal consistency, however, provides deeper analysis of themes and principles in order to extend assessment of the metaphor data points. While a crucial analytical step, it also allows deeper analysis of cases which appear externally inconsistent. For example, respondent 12 described the library profession as 'Librarianship is like cooking festive meals for strangers', and their view of them self 'like the heart of the library'. While externally inconsistent, internal consistency can, by interpretation, be established by the core theme of being a central figure within a greater system characterized by service to others, whether people or a living organism. 
Metaphors were analysed alongside the critical incident and its meaning to establish whether there was inter-consistency between the two. Continuing from the previous example, the idea of the raison d'etre of librarianship as being of service to others is strengthened when taking into account the respondent's critical incident:
Being sole person at a branch library. Frankly, there's no one else around to be 'the real librarian' so I guess it's me. In the early 2000's, leading a team of just-out-of-uni library workers (a.k.a. library assistants) with multiple degrees and mega student loans, but no formal library qualifications, to provide internet based interlibrary loan services to academics. A move that cause shock and horror from people who hated the internet but who'd been paid by their employer to do the library certificate in Wellington in 1973. (Respondent 12)

The meaning ascribed to this incident by the respondent was: 'It's customer service, it's customer service, it's customer service'. A series or collection of incidents was detailed, indicating this respondent does not necessarily attribute a single event as the most influential on their professional identity. Since a collection was stated by the respondent, the entirety of what they expressed is accommodated within this analytical framework. This response suggests service orientation as a core motivator when considered with the critical incident as a holistic data point. Extended analysis highlights an inter-consistency between data fields, affirming the core themes, while also providing further context for the metaphors and allowing more substantive themes to emerge from interpretive analysis, e.g., leadership, a willingness to step into a role that may be isolating due to service orientation. The incident illustrates the respondent was relied upon to ensure that services functioned both generally and during a time of transition, just as cooking for strangers is for the benefit of others and a heart beats to ensure a functioning system. These data points, when considered and analysed together, can be understood as inter-consistent. Inter-consistency analyses metaphors with the critical incident and its meaning to establish general consistency among these data points. Inter-consistency is applied to both metaphors and critical incidents as a holistic data unit (case). Inter-consistency is the reasonable interpretation that critical incidents and metaphors are connected, displaying a relationship where one may suggest reasoning for the other, or providing an interpretive, extended explanation either from one data point to another or reciprocally.

Finally, inter-consistent cases were analysed for metaphor framing and critical incident framing. Framing for respective metaphors can be understood as the type of comparison made in relating the two constructs. Specifically, this paper understands metaphor framing as being further defined by its comparative and descriptive relationship in reference to one of the following: 1. concrete: comparison is with a tangible, or real-world object; 2 . abstract: comparison is conceptual, with a concept, idea, or otherwise intangible construct; or 3. aspects of both: comparison either utilises or mixes both the conceptual and tangible.

Critical incident framing can be defined as the relationship between the occurrence of event(s) relative to the level at which they transpired within the professional context. Specifically, critical incident framing is further defined by its descriptive relationship in reference to one of the following: 1. local level: event(s) occurring at or directly relating to a one's immediate occupational setting or scope of influence, such as an individual library setting, or interaction with a local factor; 2 . professional level: event(s) occurring at or directly relating to the wider occupational context, such as a professional association body, conference; or 3. aspects of both: framing either utilises or mixes both the local and professional level in a meaningful way such that neither the above codes may be applied exclusively. Appendix A outlines the coding scheme used in this study, which was iteratively developed through extensive peer consultation.

This analytical approach provides an effective method to understand the perspective of the respondents. As can be seen with the metaphorical approach used in this study, views of a profession and of the self within the profession may not appear to be well connected. They are, however, tied 
together by deeper themes which are illuminated and reinforced by the explanation of critical incidents and their meanings.

\section{Results}

Note that Results inverts discussion of metaphors and critical incidents from the procedure outlined above to facilitate ease of understanding.

\section{Response \& respondent composition for all cases}

The questionnaire yielded 181 responses, 131 of which provided sufficient data to be included for analysis for the wider research project. Of the 131 responses, seventy-five participants (57\%) answered at least one of the four open-ended questions asking for metaphors and a critical incident and its meaning. Fifty-nine participants $(45 \%)$ provided complete and viable responses for all four open-ended questions. As defined in the section Analytical approach, each instance of analytically viable responses addressing all four open-ended questions was defined as a case. This paper only reports on the analysis of analytically viable cases $(\mathrm{N}=59)$ from the questionnaire. Furthermore, cases coded as inter-consistent were analysed beyond the content analysis step. Unless otherwise noted, reporting will focus on the 53 cases coded as inter-consistent.

The majority of the complete sample $(\mathrm{N}=59)$ were New Zealand European $(\mathrm{n}=47,79.7 \%)$, and of New Zealand nationality $(n=50,84.7 \%)$, revealing a homogenous sample. This sample also included representation of other ethnicities including Māori, Asian, and Pacifica. Due to size and location of the population, reporting specific ethnicities and nationalities beyond the above would risk confidentiality. Table 1 outlines demographic information related to respondent composition. Table 2 outlines factors relating to respondent entrance into librarianship. Table 3 outlines role and professional context at time of respondent reporting. These tables provide demographic information contextualising respondents and situating the data provided.

\begin{tabular}{llll}
\hline & & Respondents & Percentage \\
\hline Gender $^{1}$ & Female & 50 & $84.7 \%$ \\
& Male & 8 & $13.6 \%$ \\
\hline Age range $^{1}$ & $18-24$ & & \\
& $25-34$ & 3 & $5.1 \%$ \\
& $35-44$ & 7 & $11.9 \%$ \\
& $45-54$ & 7 & $11.9 \%$ \\
& $55-64$ & 21 & $35.6 \%$ \\
& $65-74$ & 15 & $25.4 \%$ \\
& & 5 & $8.5 \%$ \\
\hline
\end{tabular}

${ }^{1} 1$ respondent did not answer.

Table 1. General composition of respondents. 


\begin{tabular}{|c|c|c|c|}
\hline & & Respondents & Percentage \\
\hline \multirow{2}{*}{$\begin{array}{l}\text { Entered librarianship from } \\
\text { another profession }\end{array}$} & Yes & 38 & $64.4 \%$ \\
\hline & No & 21 & $35.6 \%$ \\
\hline \multirow{2}{*}{$\begin{array}{l}\text { Held library qualification with } \\
\text { first library position }\end{array}$} & Yes & 2 & $3.4 \%$ \\
\hline & No & 57 & $96.6 \%$ \\
\hline \multirow{2}{*}{$\begin{array}{l}\text { Worked outside public library } \\
\text { subsector }\end{array}$} & No & 24 & $40.7 \%$ \\
\hline & Yes & 35 & $59.3 \%$ \\
\hline \multirow[t]{7}{*}{ Previous library subsectors $^{1}$} & Academic & 16 & $27.1 \%$ \\
\hline & Business & 1 & $1.7 \%$ \\
\hline & Ministerial & 2 & $3.4 \%$ \\
\hline & National & 7 & $11.9 \%$ \\
\hline & $\begin{array}{l}\text { Parliamentary/ } \\
\text { Legislative }\end{array}$ & 1 & $1.7 \%$ \\
\hline & School & 14 & $23.7 \%$ \\
\hline & Special/Other & 8 & $13.6 \%$ \\
\hline
\end{tabular}

${ }^{1} 15$ respondents indicated two or more previous subsectors; Percentages representative of $\mathrm{N}=59$

Table 2. Entrance into librarianship.

\begin{tabular}{|c|c|c|c|}
\hline & & Respondents & Percentage \\
\hline \multirow{8}{*}{$\begin{array}{l}\text { Library and information } \\
\text { science/studies } \\
\text { qualification(s) }\end{array}$} & Sub-degree level & 18 & $30.5 \%$ \\
\hline & Degree level & 11 & $18.6 \%$ \\
\hline & $\begin{array}{l}\text { Postgraduate or higher } \\
\text { level }\end{array}$ & 23 & $39 \%$ \\
\hline & Currently pursuing & 3 & $5.1 \%$ \\
\hline & Professional & 27 & $61.4 \%$ \\
\hline & $\begin{array}{l}\text { Association Registration } \\
\text { (RLIANZA) }\end{array}$ & & \\
\hline & Currently pursuing & & \\
\hline & RLIANZA & 2 & $4.5 \%$ \\
\hline \multirow{7}{*}{$\begin{array}{l}\text { Years worked in } \\
\text { librarianship }^{1}\end{array}$} & $0-5$ & 7 & $11.9 \%$ \\
\hline & $6-11$ & 10 & $16.9 \%$ \\
\hline & $12-17$ & 14 & $23.7 \%$ \\
\hline & $18-23$ & 8 & $13.6 \%$ \\
\hline & $24-29$ & 10 & $16.9 \%$ \\
\hline & $30-35$ & 6 & $10.2 \%$ \\
\hline & $36+$ & 3 & $5.2 \%$ \\
\hline \multirow[t]{5}{*}{ Hours per week worked ${ }^{1}$} & $1-10$ & 2 & $3.4 \%$ \\
\hline & $11-20$ & 0 & $0 \%$ \\
\hline & $21-30$ & 7 & $11.9 \%$ \\
\hline & $31-40$ & 37 & $62.7 \%$ \\
\hline & $41+$ & 12 & $20.3 \%$ \\
\hline \multirow[t]{3}{*}{ Library setting $^{2}$} & Urban & 36 & $61 \%$ \\
\hline & Suburban & 10 & $16.9 \%$ \\
\hline & Rural & 11 & $18.6 \%$ \\
\hline \multirow[t]{2}{*}{ Association membership $^{1}$} & Yes & 44 & $74.6 \%$ \\
\hline & No & 14 & $23.7 \%$ \\
\hline
\end{tabular}

\footnotetext{
1 respondent did not answer.

22 respondents did not answer.
}

Table 3. Respondent contexts within librarianship 


\section{Critical incident(s)}

Note that cases coded as inter-consistent were analysed beyond the content analysis step. Unless otherwise noted, reporting of results beyond the content analysis step will focus on the 53 cases coded as inter-consistent.

A number of respondents articulated multiple critical incidents $(28,52.8 \%, \mathrm{n}=53)$. Accommodation of multiple incidents was built into this question due to feedback from the pre- and pilot testing stages of the questionnaire, as noted above. Singular incidents composed the second largest group $(n=21$, $39.6 \%)$, with continuous incidents were third $(n=4,7,5 \%)$. Continuous incidents indicate the reoccurrence of a generalised event, e.g., Respondent 3 detailed 'The rise of community street libraries'.

Participant understanding, and definition, of a critical incident differs from definitions provided in the literature (Flanagan, 1954; Hutchins \& Rainbolt, 2017). While perhaps also differing from Angelides (2010), the data from this study supports the assertion that the definition of incident and its criticality are from the meaning given to them by participants. These examples maintain elements relating to formal definitions of critical incidents such as sufficient completeness, clear intent, and definite consequences permitting inference (Flanagan, 1954). The data from this study are, however, more consistent with practice and reflective of respondent conceptualisations of critical incidents.

Respondent data indicate that critical incidents can differ from previous understandings and have an on-going, situational element to them.

\section{Sentiment analysis}

Sentiment analysis was applied to both critical incident and metaphor data points. Twenty-six $(49.05 \%, \mathrm{~N}=53)$ were coded as only presenting a positive sentiment and four $(7.5 \%)$ were coded as only presenting a negative sentiment. Twenty-two $(41.5 \%)$ were coded as presenting aspects of both positive and negative sentiments. One $(1.8 \%)$ was coded as ambiguous, unable to be determined due to multiple viable interpretations. This may have been due to the nature of the response, as it was too terse to be determined beyond ambiguity.

Twenty-six cases displayed only positive sentiments in their responses, indicating only positive critical incidents influencing or explaining their view of the profession and/or self within the profession. Twenty-two cases displayed aspects of both acknowledging some equivocation, suggesting a coexistence within their own professional self- and worldview. This coexistence was not necessarily equal between positive and negative sentiments. The differences in sentiment balancing are illustrated in Tables 4 and 5.

\begin{tabular}{|c|c|c|c|}
\hline \multicolumn{4}{|l|}{ Respondent 26} \\
\hline Critical incident & $\begin{array}{l}\text { Explanation of meaning } \\
\text { of critical incident }\end{array}$ & $\begin{array}{l}\text { Metaphor of } \\
\text { profession }\end{array}$ & $\begin{array}{l}\text { Metaphor of } \\
\text { self }\end{array}$ \\
\hline $\begin{array}{l}\text { I had a burnout. Doing } 3 \text { jobs } \\
\text { even as a multitasking female } \\
\text { was just too much. I had been } \\
\text { asked to do an acting job of a } \\
\text { branch with } 3 \text { staff for six } \\
\text { months. I still had my official } \\
\text { job and another location I } \\
\text { looked after. It lasted five years } \\
\text { and what broke me was being } \\
\text { told not to get a replacement } \\
\text { for a staff member going on } \\
\text { maternity leave.' }\end{array}$ & $\begin{array}{l}\text { 'Since then I have become more } \\
\text { confident and clear in what I } \\
\text { am and want to be. I also } \\
\text { realized that because I cared } \\
\text { about my staff did not mean } \\
\text { that my manager was doing the } \\
\text { same. It made it clear to me } \\
\text { that my happiness lies with me } \\
\text { not depending on others. In my } \\
\text { performance appraisals I am } \\
\text { now most happy [to] tell what I } \\
\text { have [achieved] and I know it } \\
\text { was great but if my managers } \\
\text { does not agree as it might not }\end{array}$ & $\begin{array}{l}\text { '... a super-librarian } \\
\text { business where you } \\
\text { really need to know } \\
\text { everything.' }\end{array}$ & $\begin{array}{l}\text { '...a 24/7 super- } \\
\text { librarian...' }\end{array}$ \\
\hline
\end{tabular}




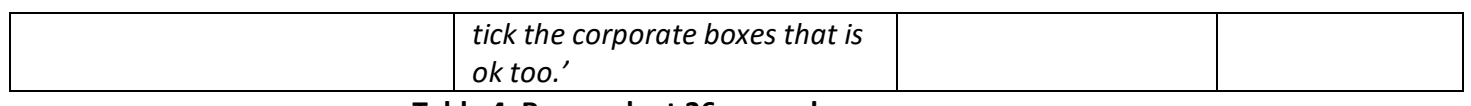

Table 4. Respondent 26 example

Respondent 26 (Table 4) details burnout leading to a positive outcome. Their metaphors share themes of high-level multitasking, the outcome of which is not always pleasant. The explication of meaning provides a negative incident with a positive outcome, interpreted as such due to its perceived influence on self-perception. The incident provided a way to understand and articulate boundaries and capabilities, reinforcing the metaphorical view of self as super-librarian and the profession as a super-librarian business. Thus, this is an example of a positive perception of a negative incident, supported by the metaphorical statements. Other cases, however, provided examples of negative incidents with negative perception, without necessarily undermining support for the accompanying metaphorical statements.

\begin{tabular}{|c|c|c|c|}
\hline \multicolumn{4}{|l|}{ Respondent 56} \\
\hline Critical incident & $\begin{array}{l}\text { Explanation of meaning } \\
\text { of critical incident }\end{array}$ & Metaphor of profession & Metaphor of self \\
\hline $\begin{array}{l}\text { 'I have had some really } \\
\text { shocking events happen } \\
\text { to me like being publicly } \\
\text { groped or being verbally } \\
\text { abused and have had to } \\
\text { make decisions on } \\
\text { whether or not to call the } \\
\text { police. But I have had } \\
\text { overwhelmingly positive } \\
\text { experiences that by far } \\
\text { outweigh the negative. } \\
\text { Like doing story time for } \\
\text { kindergarten groups and } \\
\text { having them dance and } \\
\text { breaking out of their } \\
\text { shells, or having our } \\
\text { regular kids know [me] by } \\
\text { name. It's nice to have } \\
\text { that trust.' }\end{array}$ & $\begin{array}{l}\text { 'In terms of the negative } \\
\text { experiences: I have } \\
\text { learned that I need to be } \\
\text { careful when patrons } \\
\text { start to [develop] } \\
\text { acquaintanceships with } \\
\text { me in case my friendliness } \\
\text { and chattiness gets } \\
\text { misconstrued as } \\
\text { affection. This really sucks } \\
\text { because it means having } \\
\text { to be more terse or less } \\
\text { friendly least I encourage } \\
\text { people. In terms of the } \\
\text { positive: I have learned to } \\
\text { take more time with kids. } \\
\text { A lot of school aged } \\
\text { children can be shy with } \\
\text { us at first, but the more } \\
\text { time you spend talking to } \\
\text { them about their needs } \\
\text { the more you can learn } \\
\text { how to help.' }\end{array}$ & $\begin{array}{l}\text { '[City] libraries } \\
\text { functions much like the } \\
\text { city...itself. Different } \\
\text { areas must adapt to the } \\
\text { needs of the } \\
\text { surrounding } \\
\text { communities.' }\end{array}$ & $\begin{array}{l}\text { 'Like a teacher. I have } \\
\text { to deal with multiple } \\
\text { tasks of various } \\
\text { subjects and different } \\
\text { people of different } \\
\text { ages with different } \\
\text { needs (some very } \\
\text { extreme). I also have } \\
\text { to constantly make } \\
\text { sure that I am } \\
\text { providing a safe and } \\
\text { engaging } \\
\text { environment for } \\
\text { people to learn in. } \\
\text { This has to with both } \\
\text { my demeanour (sic) } \\
\text { and the layout of my } \\
\text { workplace.' }\end{array}$ \\
\hline
\end{tabular}

Table 5. Respondent 56 example

In contrast, Respondent 56 makes explicit both positive and negative sentiments. While they indicate in their critical incident that the good outweighs the bad, they nevertheless detail both sentiments and ascribe meanings for both. They explain how they adjust to the situation and/or client, and therefore emphasise their adaptability. Their metaphorical statements indicate flexibility and engagement. Thus, the respondent's metaphors, incidents and meaning are linked by the shared theme of adaptability (implying change) when engaging with the variety of those being served. While Respondent 26 illustrates a negative event leading to a positive outcome, Respondent 56 details a conscious coupling of otherwise discrete sentiments not only with the incidents and meanings, but also in the metaphorical statements. The metaphorical statements, in indicating adaptation to various needs, thus imply the necessity of dealing with both positive and negative circumstances, and therefore sentiment.

\section{Metaphor consistency External consistency}

Eleven cases $(20.7 \%, \mathrm{~N}=53)$ displayed external consistency between metaphors of the profession and self as a librarian. Table 6 provides an example. This may be due to the placement and nature of the questions. The cognitively taxing questions about metaphors were placed in the middle of the questionnaire and this could have impeded creative coherence. Similarly, as the majority of responses 
were logged during the traditional working day, time constraints may have placed parameters on the nature of the responses. External consistency provides a symmetry of imagery, and therefore an implied symmetry of worldview as it relates to the profession and self as practitioner. External consistency, however, does not necessarily account for the core themes invoked across the metaphor data points.

\begin{tabular}{|l|l|}
\hline Respondent 18 & Metaphor of self \\
\hline Metaphor of profession & "A small honeybee in a garden of flowers.' \\
\hline 'The library profession is like a beehive.'
\end{tabular}

Table 6. Respondent 18 metaphors example.

\section{Internal Consistency}

Forty-seven cases $(88.6 \%, \mathrm{~N}=53)$ displayed an internal consistency, where an underlying theme(s) or principle(s) was established and maintained. For example, Table 7 shows Respondent 14's metaphors for the profession and themselves.

\begin{tabular}{|l|l|}
\hline \multicolumn{2}{|l|}{ Respondent 14} \\
\hline Metaphor of profession & Metaphor of self \\
\hline $\begin{array}{l}\text { 'An insecure leaking dinghy on a storm tossed } \\
\text { sea.' }\end{array}$ & $\begin{array}{l}\text { 'The missionary realized that not bringing her books to } \\
\text { the high feast may have been a mistake.' }\end{array}$ \\
\hline
\end{tabular}

Table 7. Respondent 14 metaphors example

Neither metaphor overtly provides an extension of, or a complement to, the other. Content analysis, however, revealed core themes of (lack of) control, being subject to outside forces, and perhaps a gatekeeper mentality because of a possible lack of control. Both examples identify insecurity and discomfort.

The discrepancy between internal and external consistency could illustrate an internalized perception of respondents' relationships to the profession. This discrepancy in perception suggests a worldview which is embedded and not overtly understood. Despite the apparent external inconsistency of the above metaphors, internal consistency, as derived from content analysis, suggests a coherence which is inherent or visceral because the connection between the metaphors is not overt. Thus, a symmetry is present, though deeper examination is required to establish or understand it.

\section{Content analysis}

Six cases $(11.3 \%, \mathrm{~N}=53)$, while inter-consistent with the critical incidents reported, presented metaphors that were both externally and internally inconsistent. This finding highlights two points. First, while such an arrangement may seem contradictory, the coding scheme was inductively derived, thereby accommodating a seemingly anomalous aspect which might have otherwise been omitted. Seemingly contradictory inter-related groupings, in contrast to a principle of mutual exclusivity, arose through the inductive approach and the study context. Second, this particular arrangement highlights the importance of the incidents as the unifying or explanatory data point, and therefore this coding scheme and methodological approach. Table 8 provides an example of this.

\begin{tabular}{|c|c|c|c|}
\hline \multicolumn{4}{|l|}{ Respondent 34} \\
\hline Critical incident & $\begin{array}{l}\text { Explanation of } \\
\text { meaning of critical } \\
\text { incident }\end{array}$ & $\begin{array}{l}\text { Metaphor of } \\
\text { profession }\end{array}$ & Metaphor of self \\
\hline $\begin{array}{l}\text { 'As a junior librarian, I tried to instil the } \\
\text { sheer enjoyment of reading to children, } \\
\text { made them laugh, made them think, } \\
\text { encouraged the desire to learn and explore } \\
\text { more. I now see these children coming into } \\
\text { the library with their own children who run }\end{array}$ & $\begin{array}{l}\text { 'Librarians have an } \\
\text { inherent knowledge } \\
\text { that they can make a } \\
\text { difference to the } \\
\text { future.' }\end{array}$ & $\begin{array}{l}\text { 'The library is an } \\
\text { open door to a } \\
\text { room furnished in } \\
\text { the past, present } \\
\text { and future.' }\end{array}$ & $\begin{array}{l}\text { 'Depositing and } \\
\text { facilitating knowledge } \\
\text { like a bank dealing in } \\
\text { currency for the } \\
\text { mind.' }\end{array}$ \\
\hline
\end{tabular}


towards the children's area with speed,

abandonment and a need to get their

books, plonk themselves down on a cushion

and escape.'

Table 8. Respondent 34 example

Respondent 34's metaphors shown in Table 8 are inconsistent in imagery and content analysis provided no related themes. Inconsistency is reconciled through the incident, emphasising the multigenerational impact of the practitioner and their work in their metaphor of the profession and their incident and its meaning. The work itself, having encouraged the love of reading, having fun while doing so, and having 'made them think, encouraged the desire to learn and explore more' can be understood as helping by facilitating and as depositing such aspects into the mind-bank of the children. Thus, by undertaking such work and seeing the results through multiple generations, the multigenerational aspect of the influence of self within work is evident.

\begin{tabular}{|c|c|c|c|}
\hline \multicolumn{4}{|l|}{ Respondent 17} \\
\hline Critical incident & $\begin{array}{l}\text { Explanation of meaning } \\
\text { of critical incident }\end{array}$ & $\begin{array}{l}\text { Metaphor of } \\
\text { profession }\end{array}$ & Metaphor of self \\
\hline $\begin{array}{l}\text { 'A restructure where my } \\
\text { position as Interloans Librarian } \\
\text { in Information Services was } \\
\text { downgraded and the job } \\
\text { description of the basic grade } \\
\text { for being a librarian had no } \\
\text { stipulation for library or similar } \\
\text { qualifications. Information } \\
\text { Services was disestablished and } \\
\text { the emphasis across the library } \\
\text { was acquisition and promotion } \\
\text { of fiction materials.' }\end{array}$ & $\begin{array}{l}\text { 'I felt as though my value as a } \\
\text { reference librarian was } \\
\text { diminished. I was made to spend } \\
\text { less time on the desk that fielded } \\
\text { the most enquiries (as all staff } \\
\text { were treated the same whether } \\
\text { they were qualified/experienced } \\
\text { or not) so I felt as though I was } \\
\text { losing skills. My } \\
\text { knowledge/opinion was not } \\
\text { sought in the design of the new } \\
\text { help desk arrangements.' }\end{array}$ & $\begin{array}{l}\text { 'the key that opens a } \\
\text { treasure chest of } \\
\text { imagination and clues } \\
\text { to all the wonders of } \\
\text { the world' }\end{array}$ & $\begin{array}{l}\text { 'An elephant } \\
\text { remembering the } \\
\text { knowledge of her } \\
\text { ancestors, sensing its } \\
\text { environment and } \\
\text { looking out for better } \\
\text { ways to communicate } \\
\text { information relevant to } \\
\text { the herd.' }\end{array}$ \\
\hline
\end{tabular}

Table 9. Respondent 17 example

Respondent 17 (Table 9) shows the metaphor of the profession as providing a mechanism for access. The metaphor does not seem consistent with the metaphor of self as positioned with reference to a group. The critical incident would suggest that the effects of change are both positive and negative. While the negative is keenly observed, indicated benefits include wisdom (remembering the importance of previous knowledge amidst change), increased awareness, and improved communication skills as they relate to the group. The view of the profession maintains a positive tone through imagery, language, and interpreted meaning. The critical incident prompted a change of behaviour and outlook as communicated through the metaphor of self, while the professional metaphor appears otherwise unaffected as compared with the other three data points. While a negative sentiment can be readily identified in the critical incident, it appears not to have negatively influenced perceptions of self and profession as presented in the metaphors. The critical incident alludes to what is lost when knowledge, experience, and expertise are ignored or forgotten.

The cases presented in Tables 8 and 9 present apparently unrelated metaphors when taken separately from their incidents and meanings. The coding scheme reflects their disparate nature. It is through the content analysis that inter-consistency can be established regardless of metaphorical inconsistencies. Such cases illustrate how influential local context of practice can be on perception of self as practitioner, regardless of metaphorical perception of the profession or overall sentiment of a case.

\section{Framing}

Additional analysis assessed participant framing of metaphors and incidents, as respectively defined in the Analytical approach section.

\section{Critical incidents}

The analytical emphasis of critical incident framing was placed on occurrence of the event(s) relative to the level at which they transpired. As noted, the incidents were coded as one of three categories: 1 . 
local level, occurring at or directly relating to a particular area or one's immediate occupational setting or scope of influence; 2 . professional level, occurring at or directly relating to the wider occupational context; and 3. aspects of both, either utilising or mixing the local and professional levels in a meaningful way such that neither of the other codes could be applied exclusively. Most incidents transpired at the local level $(44,83 \%, \mathrm{~N}=53)$. However, some are reported as occurring on the professional level $(6,11.3 \%)$, and three cases $(5.6 \%)$ were coded as both, articulating multiple incidents spanning both levels. Table 10 presents examples for each framing level code.

\begin{tabular}{|l|l|l|}
\hline Respondent & Critical incident & Framing level code \\
\hline 57 & $\begin{array}{l}\text { 'Using my multiple communications skills to help someone learn } \\
\text { to use computer, write their CV and then learn that the person } \\
\text { has, as a result, got a job and then help the same person with } \\
\text { readers advisory for work and pleasure' }\end{array}$ & Local level \\
\hline 15 & $\begin{array}{l}\text { 'being involved at a regional, national and international level } \\
\text { speaking at and attending conferences working in children's } \\
\text { services' }\end{array}$ & Professional level \\
\hline 31 & $\begin{array}{l}\text { '- being told I'd make a great Librarian, if I gained a formal } \\
\text { qualification - getting my HT licence to drive the Mobile - being } \\
\text { asked to apply for the Library Managers role - being asked to } \\
\text { Chair APLM - using my community services experience to develop } \\
\text { strong community engagement programmes and services' }\end{array}$ & Both \\
\hline
\end{tabular}

Table 10. Critical incident framing examples

\section{Metaphor of profession}

Metaphor framing can be understood as the type of comparison made in relating two constructs. It is further defined by its comparative and descriptive relationship in reference to one of three categories: 1. concrete comparison with a tangible, or real-world object; 2 . abstract comparison with a concept, idea, or otherwise intangible construct; and 3. aspects of both, either utilising or mixing tangible and conceptual. Cases coded as abstract $(\mathrm{n}=9,16.9 \%, \mathrm{~N}=53)$ accounted for the smallest group, while those coded as concrete and both ( $\mathrm{n}=22,41.5 \%$ respectively) were equally represented. Table 11 presents examples for each framing level code.

\begin{tabular}{|l|l|l|}
\hline Respondent & Metaphor of profession & Framing level code \\
\hline 7 & $\begin{array}{l}\text { '...a small but luxuriant oasis in the middle } \\
\text { of the desert' }\end{array}$ & Concrete \\
\hline 41 & 'A force for good in society.' & Abstract \\
\hline 23 & $\begin{array}{l}\text { 'The library is like an island on a vast sea of } \\
\text { ignorance' }\end{array}$ & Both \\
\hline
\end{tabular}

Table 11. Metaphor of profession framing examples

\section{Metaphor of professional self}

Most cases framed professional self as concrete $(44,83 \%, \mathrm{~N}=53)$, while abstract $(5,9.4 \%)$ and both $(4,7.5 \%)$ showed near equal representation. Table 12 presents examples for each framing level code.

\begin{tabular}{|l|l|l|}
\hline Respondent & Metaphor of professional self & Framing level code \\
\hline 18 & 'A small honeybee in a garden of flowers.' & Concrete \\
\hline 36 & $\begin{array}{l}\text { 'ma whero, ma pango, ka oti ai te mahi } \\
\text { "With red and black the work will be } \\
\text { complete" This refers to co-operation where } \\
\text { if everyone does their part, the work will be } \\
\text { complete.' }\end{array}$ & Abstract \\
\hline 21 & $\begin{array}{l}\text { 'An iron core of integrity; a piece of } \\
\text { plasticine that moulds itself into what is } \\
\text { needed' }\end{array}$ & Both \\
\hline
\end{tabular}

Table 12. Metaphor of professional self framing examples

Inter-inconsistent responses 
It should be noted that six cases of the total collected $(\mathrm{N}=59,10 \%)$ were coded as inter-inconsistent (i.e. there was inconsistency between the critical incidents and the metaphors) and have been excluded from the above analysis, which focuses on inter-consistent cases. Inconsistency denotes two possibilities. First, in using this methodological approach, not all respondents may provide sufficient data to be considered for further analysis. Second, responses providing sufficient data may still result in inconsistency, which was the case here.

\section{Discussion}

Respondent conceptualisations of $\operatorname{critical}$ incident( $s$ ) illustrate that for this respondent group, the number and duration of incidents provide a layer of complexity and expand traditional definitions of what is critical, and what is an incident. As mentioned above, respondents provided data that shares elements with formal definitions of critical incidents yet diverge by incorporating on-going, situational elements. The data support the assertion that definition is reliant on the meaning given to any such event, and are reflective of practice within this sample (e.g., Respondent 34, Table 8). This important finding is reflected in the analytical framework. As it was inductively derived, this suggests the framework will accommodate, and therefore be more reflective of, practice and the professional identities within it.

Similarly, respondent conceptualisations of metaphors necessitated a definition of metaphor that differs from other formal definitions (e.g., Lakoff \& Johnson, 1980). This study accepted metaphors for analysis presenting or maintaining a comparison between objects, actions, or constructs. We suggest this is in accordance with a function of metaphor (to compare) and in alignment with the shift of analytical focus this approach presents. This result may be reflective of respondents' worldview or other factors contributing to their understanding such as the critical incidents impacting their perception in the time and place such perception is situated. The metaphorical definition that this study presents serves to create a more achievable threshold for analysis inclusion for what is a cognitively taxing process. This definition contributes to the flexibility of the approach.

The critical incidents were often the key data point. It was through the critical incidents that interconsistency was established and provided suggested reasoning for and relationship with the metaphors. Critical incidents differed case by case as to which metaphor (self or professional) they related. Often, an incident would immediately support the metaphor of self. Other times, it would support the metaphor of the profession, and sometimes it would support both. Analysis within the framework as described in the Analytical approach section required an individualistic approach, focusing on each case as its own occurrence, to accommodate idiosyncrasies. The inductive approach assisted in understanding whether trends could be established across cases. Content analysis as defined in this study is therefore not simply a bridging step in analysis, but rather fundamental to uncover the relationships between data points.

Framing is a useful analytical emphasis, because it suggests participant perception of their relationship to the profession and their identity within its context. Professional identity is indicative of the relation between the practitioner's self and a collective (Whyte, 1956/2002). This relationship influences discourse and behaviour (Sundin \& Hedman, 2009) and varies according to the individual within the collective, professional context. How an individual is affiliated with a profession is suggestive of their perception of it and their self within or outside it, indicating a relationship between identity, perception, and collective affiliation and its degrees (Fraser-Arnott, 2017a). Framing, as outlined in this paper, allows a deeper examination of and an analytical lens to explore degrees of affiliation. This exploration is accessed through how respondents express their perception of the profession and their relation to it by the way they frame their responses. For critical incidents, it provides an indication of the level at which such event(s) can occur. For metaphors, it illuminates self- and worldview as including elements that are concrete, abstract, or some combination of both. The resulting interplay, when analysing both metaphors together, further suggests a new line of inquiry where framing for metaphors of self differs from those of the profession. 
The above analysis does not take into account data resulting from interviews that followed the collection of data through the questionnaire. While the interviews in Phase two provided deeper exploration into meanings assigned to metaphors and critical incidents, the responses in Phase one provided a strong entry point to analysis. This study indicates elicitation of metaphors and critical incidents through the use of a questionnaire is a viable methodological approach. It also indicates great potential for future development. The pre- and pilot testing phases of this study highlight the need for such testing to adapt the questions meaningfully and manageably for the target community.

The methodological approach outlined here provides a powerful way to examine professional identity as conceptualised for this study using Whyte's (1956/2002) conceptualisation. This includes emphasis of the impact of critical incidents on identity development and that perception of this impact informs the course of identity development. This perception additionally influences self- and worldview and is bounded by the dynamics of the Librarian Professional Identity Continuum model developed by the authors (Pierson et al., 2019). It was inductively derived, providing specificity, flexibility, and offering economies of scale according to the research objectives. This methodological approach is grounded in research underpinned by a sociological understanding of professional identity, whose development is influenced by time and social interaction. Such underpinning suggests additional opportunities in comparative or longitudinal research where one data case provides a snapshot in a particular time and context. Moreover, as an emergent approach, its adoption includes an imperative to modify and refine its use and application with exploration of its analytical scope.

\section{Limitations and future research}

The approach outlined focuses on individual experiences of fifty-nine participants in one country. The authors' subjectivity informed the nuanced analysis and interpretation, requiring reflective attention throughout the research process. While some responses were not necessarily written as traditional metaphors, those included for analysis provided the spirit of a metaphor, maintaining a comparison. A main limitation, therefore, is the untested transferability of the research to other countries and professions.

Future research could seek to apply this methodological approach in other contexts, localities, or professions. Additionally, there is potential to confirm the wider usefulness of the approach and explore modifications. Of particular note, future research could examine the occurrence of metaphor consistency within this or another field. Finally, the scope of this paper only included within-case analysis. Future research could include among case analysis in scope.

\section{Conclusion}

This paper has presented a methodological approach combining metaphor elicitation and the critical incident technique applied through open-ended questions in questionnaire format. It illustrates the data elicited from both methods as complementary within a wider analytical structure, where often mutual support can be established between the two data points. Results indicate that metaphors, as explication of implicit and explicit worldviews, can be explained by critical incidents detailed by respondents. This approach provides an effective method to investigate deeper themes being expressed by respondents, thereby providing a link between worldview as expressed by metaphors and that which is detailed in critical incidents and their meanings. As a newly developed approach, executed in a non-traditional manner from its parent methodologies, caution is required in analysis and interpretation of results. Additional work is required to understand the extent of its applicability and usefulness for future research. Tailoring to circumstantial need may be a persistent feature of this approach. Nevertheless, the combined metaphorical-critical incident technique (MCIT) method shows potential for contributing to future research in a variety of settings and contexts. In particular, this method has unique applicability in understanding professional identity within librarianship and the wider information fields. 


\section{References}

Ahmed, K. (2012). Forming working selves: flexibility and generational identity formation in the public library [Master Thesis, Carleton University (Canada)]. ProQuest Library Science. 
Angelides, P. (2010). The development of an efficient technique for collecting and analyzing qualitative data: the analysis of critical incidents. International Journal of Qualitative Studies in Education, 14(3), 429-442. https://doi.org/10.1080/09518390110029058

Bak, G. (2002). "The greatest librarians of the world...were not graduates of library school". Libraries \& Culture, 37(4), 363-378. https://doi.org/10.1353/lac.2002.0067

Bennett, G. E. (1988). Librarians in search of science and identity: the elusive profession. The Scarecrow Press.

Cheok, J., Hede, A.-M., \& Watne, T. A. (2015). Explaining cross-cultural service interactions in tourism with Shenkar's cultural friction. Current Issues in Tourism, 18(6), 539-560. https://doi.org/10.1080/13683500.2013.860955

Dervin, B. (2008). Interviewing as dialectical practice: sense-making methodology as exemplar. International Association for Media and Communication Research Annual Meeting, Sweden.

Flanagan, J. C. (1954). The critical incident technique. Psychological Bulletin, 5, 327-358.

Fraser-Arnott, M. (2016). The value of the MLS or MLIS degree: transferable skills identified by LIS graduates in non-library roles. The Bottom Line, 29(3), 129-141. https://doi.org/10.1108/BL-03-2016-0015

Fraser-Arnott, M. (2017a). Identifying as a librarian: when LIS graduates in non-library roles use the title "librarian". The Canadian Journal of Information and Library Science, 41(3), 186-210. https://muse.jhu.edu/article/686189

Fraser-Arnott, M. (2017b). Personalizing professionalism: the professional identity experiences of LIS graduates in non-library roles. Journal of Librarianship and Information Science, 51(2), 431-439. https://doi.org/10.1177/0961000617709062 (Archived by Internet Archive at https://bit.ly/2ShGC3H)

Frye, J. M. (2018). Assimilation or humiliation? An analysis of professional identities after critical events in the workplace. School Library Research, 21, 1-27. https://files.eric.ed.gov/fulltext/EJ1182161.pdf

Gaston, N. M., Dorner, D., \& Johnstone, D. (2015). Spirituality and everyday information behaviour in a non-Western context: sense-making in Buddhist Laos. Information Research, 20(2), paper 665.

http://www.informationr.net/ir/202/paper665.html (Archived by WebCite® at http://www.webcitation.org/6Z1Ewu9XF)

Giesecke, J. (2010). Finding the right metaphor: restructuring, realigning, and repackaging today's research libraries. Journal of Library Administration, 51(1), 54-65. https://doi.org/10.1080/01930826.2011.531641

Gogan, J., McLaughlin, M.-D., \& Thomas, D. (2014). Critical incident technique in the basket Thirty Fifth International Conference on Information Systems, Auckland, New Zealand.

Gold, Y. (1996). Beginning teacher support: attrition, mentoring, and induction. In J. Sikula (Ed.), Handbook for research on teacher education (pp. 548-594). Macmillan.

Greyson, D. M., Surette, S. M., Dennett, L. M., \& Chatterley, T. M. (2013). "You're just one of the group when you're embedded": report from a mixed-method investigation of the research-embedded health librarian experience. Journal of the Medical Library Association, 101(4), 287-297. 
Harris, R. (1992). Librarianship: the erosion of a woman's profession. Ablex Publishing Corporation.

Hartel, J., \& Savolainen, R. (2016). Pictorial metaphors for information. Journal of Documentation, 72(5), 794-812. https://doi.org/10.1108/JD-07-2015-0080

Hekkala, R., Stein, M.-K., \& Rossi, M. (2018). Metaphors in managerial and employee sensemaking in an information systems project. Information Systems Journal, 28(1), 142-174. https://doi.org/10.1111/isj.12133

Helkkula, A., \& Pihlström, M. (2010). Narratives and metaphors in service development. Qualitative Market Research, 13(4), 354-371. https://doi.org/10.1108/13522751011078791

Hicks, D. (2014a). The construction of librarians' professional identities: a discourse analysis. Canadian Journal of Information and Library Science, 38(4), 251-270. https://doi.org/10.1353/ils.2014.0017

Hicks, D. (2014b). Information technology, change and information professionals' identity construction: a discourse analysis. Proceeding of the American Society Information Science and Technology, Seattle, WA.

Hicks, D. (2016). Person or place: rhetorical construction of librarian and library by the information profession community. Canadian Journal of Information and Library Science, 40(4), 318-331.

Hoffman, K. (2014). "You can't learn it in school": field experiences and their contributions to education and professional identity. Canadian Journal of Information and Library Science, 38(3), 220-238.

Hughes, H. (2012). An expanded critical incident approach for exploring information use and learning. Library and Information Research, 36(112), 72-95.

Hutchins, H. M., \& Rainbolt, H. (2017). What triggers imposter phenomenon among academic faculty? a critical incident study exploring antecedents, coping, and development opportunities. Human Resource Development International, 20(3), 194-214. https://doi.org/10.1080/13678868.2016.1248205

Kuhlthau, C. (1991). Inside the search process: Information seeking from the user's perspective. Journal of the American Society for Information Science, 42(5), 361371.

Lakoff, G. (1987). Women, fire, and dangerous things: what categories reveal about the mind. University of Chicago Press.

Lakoff, G., \& Johnson, M. (1980). Metaphors we live by. University of Chicago Press.

Linton, A. M. (2016). Emerging roles for librarians in the medical school curriculum and the impact on professional identity. Medical Reference Services Quarterly, 35(4), 414-433. https://doi.org/10.1080/02763869.2016.1220758

Luparell, S. (2004). Faculty encounters with uncivil nursing students: an overview. Journal of Professional Nursing, 20(1), 59-67. https://doi.org/10.1016/j.profnurs.2003.12.007

Marshall, H. H. (1990). Metaphor as an instructional tool in encouraging student teacher reflection. Theory Into Practice, 29(2), 128-132.

Mills, J., \& Lodge, D. (2006). Affect, emotional intelligence and librarian-user interaction. Library Review, 55(9), 587-597. https://doi.org/10.1108/00242530610706770

Myers, M. D. (2013). Qualitative research in business and management. SAGE.

Nelson, A. J., \& Irwin, J. (2014). “Defining what we do-all over again”: occupational identity, technological change, and the Librarian/Internet-search relationship. Academy of Management Journal, 57(3), 892-928. https://doi.org/https://doi.org/10.5465/amj.2012.0201 
Pagowsky, N., \& Rigby, M. (Eds.). (2014). The librarian stereotype: deconstructing perceptions \& presentations of information work. Association of College and Research Libraries.

Patton, M. Q. (2002). Qualitative Research and Evaluation Methods. Sage.

Peters, B. G. (2013). Institutional theory. In M. Bevir (Ed.), The SAGE handbook of governance (pp. 78-90). Sage.

Pickard, A. J. (2013). Research methods in information (2nd ed.). Facet Publishing.

Pierson, C. M., Goulding, A., \& Campbell-Meier, J. (2019). An integrated understanding of librarian professional identity. Global Knowledge, Memory and Communication, 68(4/5), 413-430. https://doi.org/10.1108/GKMC-01-2019-0008

Poulou, M. (2003). Reflections of pre-service psychologists on the role of the school psychologist. School Psychology International, 24(4), 378-393.

Preer, J. L. (2006). "Louder please”: using historical research to foster professional identity in LIS students. Libraries \& the Cultural Record, 41(4), 487-496.

Radford, M. L. (2006). The Critical Incident Technique and the qualitative evaluation of the Connecting Libraries and Schools Project. Library Trends, 55(1), 46-64.

Sare, L., \& Bales, S. E. (2014). Professional identity: a grounded theory study of veteran academic librarians. Library Review, 63(8/9), 574-589. https://doi.org/10.1108/LR-02-2014-0020

Sare, L., Bales, S. E., \& Neville, B. (2012). New academic librarians and their perceptions of the profession. Portal : Libraries and the Academy, 12(2), 179-203. https://doi.org/10.1353/pla.2012.0017

Savolainen, R. (2006). Information use as gap-bridging: the viewpoint of sense-making methodology. Journal of the American Society for Information Science and Technology, 57(8), 1116-1125. https://doi.org/10.1002/asi.20400

Savolainen, R., \& Kari, J. (2004). Placing the Internet in information source horizons: a study of information seeking by Internet users in the context of selfdevelopment. Library \& Information Science Research, 26(4), 415-433. https://doi.org/10.1016/i.lisr.2004.04.004

Schmitt, R. (2005). Systematic metaphor analysis as a method of qualitative research. The Qualitative Report, 10(2), 358-394. https://nsuworks.nova.edu/tqr/vol10/iss2/10 (Archived by Internet Archive at https://bit.ly/2W9VFNM)

Sloniowski, L. (2016). Affective labor, resistance, and the academic librarian. Library Trends, 64(4), 645-666. https://doi.org/10.1353/lib.2016.0013

Sundin, O., \& Hedman, J. (2009). Professions and occupational identities. In K.E. Fisher, S. Erdelez, \& L.E.F. McKechnie (Eds.), Theories of information behavior (pp. 293297). Information Today, Inc.

Sundin, O., \& Johannisson, J. (2005). Pragmatism, neo-pragmatism and sociocultural theory: communicative participation as a perspective in LIS. Journal of Documentation, 61(1), 23-43. https://doi.org/10.1108/00220410510577998

Trede, F., Macklin, R., \& Bridges, D. (2012). Professional identity development: a review of the higher education literature. Studies in Higher Education, 37(3), 365--384. https://doi.org/10.1080/03075079.2010.521237

VanScoy, A. (2010). Reference librarians' personal theories of practice: a new approach to studying reference service. In M. L. Radford \& R. D. Lankes (Eds.), Reference renaissance: current and future trends (pp. 115-128). Neal-Schuman Publishers. 
VanScoy, A. (2016). Making sense of professional work: metaphors for reference and information service. Library \& Information Science Research, 38(3), 243-249. https://doi.org/10.1016/j.lisr.2016.08.003

Whyte, W. H. (1956/2002). The organization man. University of Pennsylvania Press.

Wise, S. (2012). Working to think otherwise: tracing ethos in information professional's reflections on learning and practice. Australian Academic and Research Libraries, 43(3), 169-188.

Zhang, Y., \& Wildemuth, B. M. (2009). Qualitative analysis of content. In B. M. Wildemuth (Ed.), Applications of social research methods to questions in information and library science (pp. 308-319). Libraries Unlimited. 


\section{Appendix A}

The coding scheme used in this study is presented to add clarity to the coding process herein described and as a framework to follow, modify, adapt, and/or refine for future use.

\section{Coding scheme}

Note: This scheme was inductively derived from the data. It incorporates a holistic approach to its application, unless otherwise noted.

\section{Definitions (OED):}

Theme, n.: 1c: That which is the subject of thought; 1a: The subject of discourse, discussion, conversation, mediation, or composition; a topic

Sentiment, n.: 8a: A thought or reflection colored by or proceeding from emotion; 6a: What one feels with regard to something; mental attitude (of approval or disapproval, etc.)...; 7a: A mental feeling, an emotion.

Analysis, n: 1a: A detailed examination or study of something so as to determine its nature, structure, or essential features; $1 \mathrm{~b}$ : The action or process of carrying out such a detailed examination; the methodical or systematic investigation of something complex in order to explain or understand it.

This process examines the data in seven ways described as follows:

1. Sentiment identification

2. Metaphor External Consistency

3. Metaphor Internal Consistency

4. Inter-consistency of the entire data set

5. Professional Metaphor framing

6. Self Metaphor framing

7. Critical Incident framing

Procedure:

1. Read all four data points to introduce self to data $->1 \mathrm{a}$. Code for Sentiment analysis

2. Make general notations on themes, keywords, contradictions, or connections $->2 \mathrm{a}$. Code for General content analysis

3. Return focus to Metaphors -> 3a. Code for Metaphor consistency analysis

4. Return focus to Critical Incidents as they may relate to the Metaphors $\rightarrow>4 a$. Code for Interconsistency

5. Return focus to Professional Metaphor -> 5a. Code for Professional Metaphor Framing

6. Return focus to Self Metaphor -> 6a. Code for Self Metaphor Framing

7. Return focus to Critical Incidents $->7$ a. Code for Critical Incident Framing

Coding \& Codes:

Below details the coding process, explanation of what is being coded for, and codes, highlighted in yellow.

1. Sentiment Analysis is coded for and considering all metaphor and critical incident data points together. Only one of the four following codes will be applied. Sentiment analysis is holistic and applies to all metaphor and critical incident data points together (the case).

- Does the entirety of what is being expressed display as:

○ only Positive: constructive action or attitudes, inclined for hope, optimistic, good, beneficial, advantageous

- only Negative: denial, disgust, dissent, distaste, devoid of positive attributes

- aspects of Both: regardless of whether one sentiment is predominate, both Positive and Negative are present

- Ambiguous: unable to be determined or may present multiple viable interpretations 
2. This step must be done in order to fully support steps 3-7.

General Content Analysis in the form of thematic analysis, where the core theme(s) being expressed are noted for all data points. Questions to consider for analysis: If present, how does the symbolism or associated meaning(s) of word(s)/phrase(s)/image(s) help illuminate deeper meaning, and therefore connections between data points? How are connections able to be established? Is an explanation of an aspect(s) more apparent now? What contradictions are apparent? Theme(s) may not be explicit, so it is vital to explicate them in analysis. General content analysis applies to both metaphors and critical incidents. Suggested approach follows left to right: 1) Metaphors, separate then together, 2) Critical Incident(s) and their meaning, 3) All data points together.

○ General notations (individual), further explanation of connections (if present).

3. Use General Content Analysis to asses:

Metaphor Consistency Analysis analyses both metaphors for their external and internal consistencies. External and Internal consistencies only apply to the metaphors. Codes must be applied for both External and Internal consistencies.

- External consistency assesses whether the same imagery is used between the two metaphors. Are they related thematically one face value by the imagery used. Is a general metaphorical theme maintained though the two metaphor data points either by extension of the first metaphor used (i.e. one metaphor is positioned within the context of the other) or is a wider theme maintained (e.g., animal kingdom is used, but different species are referenced).

$\circ \quad \mathrm{EC}=$ Externally Consistency OR

$\circ \quad \underline{E I}=$ Externally Inconsistent

- Internal consistency assesses whether the two metaphors are linked by core theme(s) or principle(s), regardless of external consistency. Internal consistency can be established by core theme(s)/principle(s), therefore allowing for internal consistency if external consistency is not present.

$\circ \quad \underline{\mathrm{IC}}=$ Internally Consistent OR

○ $\underline{\underline{\text { II }}}=$ Internally Inconsistent

4. Use General Content Analysis to asses:

Inter-consistency analyses metaphors with the critical incident, and its meaning, to establish general consistency among data points. Inter-consistency applies to both metaphors and critical incidents (holistic). It is an assessment as to their general relation. This relies on the resulting themes/notes from general content analysis and notes made from the metaphor consistency analysis. Inter-consistency applies to the metaphors and critical incidents as a holistic data point. Inter-consistency requires a minimum of three of the four individual data points to support its classification, unless one of the four data points presents a so contradictory or discordant that general consistency would otherwise be inappropriate.

- $\underline{\text { IntC }}=$ Inter-consistent: Displaying a connection between the Critical Incidents and at least one of the metaphors. There is the general tendency where one data point will at least suggest an explanation or connection of/to the other data point. Emphasis here is usually given to the metaphor of self in the profession, though this may not always be the case in practice. It may be possible to code for Inter-consistency where the metaphor describing view of the profession is otherwise an outlier.

OR

○ $\quad \underline{\text { IntIn }}=$ Inter-inconsistent: Despite analysis, no consistency is able to be established between the metaphors and the critical incidents, either due to insufficient data provided or the data provided does not support consistency.

5. Profession Metaphor Framing Analysis

Professional metaphor framing assesses how the metaphor is presented or articulated.

Framing for metaphors can be understood as the type of comparison made in relating the two constructs. Specifically, this paper understands metaphor framing as further defined by its comparative and descriptive relationship in reference to one of the following: 
- $\mathrm{C}=$ Concrete: comparison is with a tangible, or real-world object.

- $\mathrm{A}=$ Abstract: comparison is conceptual, with a concept, idea, or otherwise intangible construct.

- $\mathrm{B}=$ aspects of Both: comparison either utilises or mixes both the conceptual and tangible.

6. Self Metaphor Framing Analysis

Self metaphor framing assesses how the metaphor is presented or articulated. Framing for metaphors can be understood as the type of comparison made in relating the two constructs. Specifically, this paper understands metaphor framing as further defined by its comparative and descriptive relationship in reference to one of the following:

- $\mathrm{C}=$ Concrete: comparison is with a tangible, or real-world object.

- $\mathrm{A}=$ Abstract: comparison is conceptual, with a concept, idea, or otherwise intangible construct.

- $\quad \mathrm{B}=$ aspects of Both: comparison either utilises or mixes both the conceptual and tangible.

7. Critical Incident Framing Analysis

Critical incident framing can be defined as the relationship between occurrence of the event(s) relative to the level at which they transpired within the professional context. Specifically, critical incident framing is further defined by its descriptive relationship in reference to one of the following:

- $\mathrm{L}=$ Local level - an event(s) occurring at or directly relating to a particular area or one's immediate occupational setting or scope of influence, such as dealing with an individual library setting, interaction with a local factor, etc.

- $\quad \mathrm{P}=$ Professional level - an event(s) occurring at or directly relating to the wider occupational context, such as dealing with a professional association body, conference, etc.

- $\quad B=$ aspects of Both: framing either utilises or mixes both the local and professional level in a meaningful way such that neither the above codes may be applied exclusively. 